This is an electronic reprint of the original article. This reprint may differ from the original in pagination and typographic detail.

Author(s): Kurunsaari, Merja; Tynjälä, Päivi; Piirainen, Arja

Title: Graduating Physiotherapy Students' Conceptions of their own Competence

Year: $\quad 2018$

Version:

Please cite the original version:

Kurunsaari, M., Tynjälä, P., \& Piirainen, A. (2018). Graduating Physiotherapy

Students' Conceptions of their own Competence. Vocations and Learning, 11(1), 1-

18. https://doi.org/10.1007/s12186-017-9177-8

All material supplied via JYX is protected by copyright and other intellectual property rights, and duplication or sale of all or part of any of the repository collections is not permitted, except that material may be duplicated by you for your research use or educational purposes in electronic or print form. You must obtain permission for any other use. Electronic or print copies may not be offered, whether for sale or otherwise to anyone who is not an authorised user. 


\subsubsection{Kallen ehdotukset huomioitu. Viimeinen versio}

\section{Graduating Physiotherapy Students' Conceptions of Their Own Competence}

Merja Kurunsaari

Senior Lecturer in Physiotherapy, Lic.Sc. (Health Sciences), PT, PhD student

University of Jyväskylä, Faculty of Sport Sciences

P.O. Box 35, FI-40014 University of Jyväskylä, Finland

Phone: +358408285627

E-mail: merja.kurunsaari@jamk.fi

"Correspondent author"

Päivi Tynjälä, Professor, Dr

University of Jyväskylä, Finnish Institute for Educational Research

P.O. Box 35, FI-40014 University of Jyväskylä, Finland

Phone: +358504009464

E-mail: paivi.tynjala@jyu.fi

Arja Piirainen, Lecturer, $\mathrm{PhD}$

University of Jyväskylä, Faculty of Sport Sciences

P.O. Box 35, FI-40014 University of Jyväskylä, Finland

Phone: +358408053585

E-mail: arja.piirainen@jyu.fi

\section{Abstract}

A competency-oriented approach has recently emerged in higher education and thus far, not much attention has been paid to how "competence" itself is understood in education. The purpose of this study was to examine how graduating physiotherapy students perceive their competence at the end of their studies. The data comprised interviews with 33 graduating physiotherapy students. The data were analysed with the phenomenographic approach. The findings indicated that graduating students had different and wide-ranging conceptions of what competence in physiotherapy entails and what their own competence covers. The descriptive categories - mastering core skills, understanding the theoretical basis of physiotherapy, having a holistic view of physiotherapy, engaging in and developing multiprofessional collaboration - varied hierarchically on the basis of seven themes. From a pedagogical point of view, four critical aspects were identified: focus of reflection, professional agency, cultural awareness and communication.

Keywords: professional competence, conceptions of competence, graduating students, physiotherapy, physiotherapy students, phenomenography

[Note: The term 'competence/competences' refers to 'ability/abilities', whereas 'competency/competencies' refers to 'skill area/s' (you may wish to use these alternative terms in places where you wish to avoid ambiguity) - please consider your meaning throughout the paper (not adjusted or mentioned hereafter); see also http://answers.yahoo.com/question/index?qid $=20061005055406 \mathrm{AAlNk7B}$ and
Kommentoinut [PT1]: Ehdotan että käytämme kuitenkin tätä muoto läpi teksti. Kun nyt jossain kohdassa oli competency ja jopa samassa virkkeessä toisessa kohdassa competence niin se herättää kysymyksen mitä eroa niillä on, ja silloin se ero pitäisi selostaa tekstissä. Kukaan arvioitsijoista ei kiinnittänyt huomiota tähän asiaan joten palautetaan kaikki alkuperäiseen muotoonsa, eli competencejoten palauteta
competences 
http://www.researchgate.net/post/What_is_the_difference_between_competence_and_competencyandhttp://youremploy ment.biz/competency/competence-vs-competency/]

\section{Introduction}

A competency-oriented approach has emerged in higher education discussions and research all over the world in recent decades. For example, to ensure compatible and comparable qualifications among graduates within the European Union, the European Commission has launched the European Qualifications Framework (EQF), specifying skills, knowledge and competences at different educational levels (EQF 2008; European Commission 2014). On a more global level, the OECD recently conducted an international feasibility study on measuring learning outcomes in higher education (AHELO 2013; Organisation for Economic Co-operation and Development 2014; Tremblay, Lalancette, and Roseveare 2012).

In higher education the movement from content-centred teaching toward competence-based education has expanded in general (e.g., Bergsmann et al. 2015; Wesselink et al. 2010). At the same time, the roles of students and teachers have changed. Students are expected to be responsible for their own learning, and are encouraged to evaluate and reflect on their personal learning needs and the development of their competences. The teacher's role has transformed from "sage on the stage" to "guide on the side" (King 1993), that is, from just transmitting knowledge to guiding the learning process and encouraging students by mentoring and coaching them to reflect on their own learning processes (e.g., Mulder 2013; Nicoll and Salling Olesen 2013) and develop metacognitive, metastrategic, and epistemological competence (Rapanta, Garcia-Mila, and Gilabert 2013). Furthermore, it has been stated that identifying students' competence levels will improve students' learning processes (e.g., Achcaoucaou et al. 2014). The overall aim is to better prepare students for working in different and dynamic professional communities and for facing their professional career with more flexibility and adaptability (Mulder 2013).

In general, competency-based education (CBE)] can be defined as an educational model based on students' academic competence. The starting point of the curriculum design is the description of professional competences to be achieved, rather than disciplinary contents. Thus, learning outcomes are expressed in terms of competency statements that describe performance of professionally related functions or knowledge, skills and attitudes thought to be essential to the performance of those functions (Tuxworth 1989). Other important features of CBE include the use of realistic learning tasks, authentic learning settings and authentic assessments (Bergsmann et al., 2015; Koenen, Doghy, and Berghmans 2015; Mulder, Gulikers, Biemans, and Wesselink 2009; Mulder, 2012). Studies on CBE have been carried out in different fields from the perspective of teaching and assessment. For example, some studies have focused on implementing CBE in higher education (Koenen, Dochy, and Berghmans 2015) or on developing and facilitating students' competence development using web technologies and e-learning environments (Schneckenberg, Ehlers, and Adelsberger 2011). Some other studies have aimed to develop the concept further in order to improve the evaluation of competence-based teaching (Bergsmann et al. 2015), or to evaluate the validity of a self-report instrument for measuring competency (Khaled et al. 2014). Despite a number of studies on the subject, there are still difficulties both to explicitly describe and implement CBE (Struyven and De Meyst 2010; Yanua and Watson 2011).

In fields such as physiotherapy, medicine and nursing, professionals need diverse practical skills and competences when working with patients. Despite the wide interest in the development of professional competences, less attention 
has been paid to how "competence" itself is understood in education. Since competence development is the main target of education, it is important for all parties involved to have an explicit understanding of what competence is in the context in question. Therefore, in general, and in the context of physiotherapy in particular, there is a need for conceptual analysis regarding how teachers, students and curriculum developers conceive competences required in their field. In the present study, we begin such an analysis by examining physiotherapy students' conceptions of their own competence, because knowing how physiotherapy students see their competences may suggest critical areas that education should pay attention to in supporting students' learning and professional development. We were particularly interested in students' academic comprehension at the end of their studies, and we belief that research on graduating physiotherapy students' conceptions of their competence may also have relevance for other fields in higher education.

\section{Competence and competence development}

The concept of 'competence' is widely used in higher education, but a variety of interpretations and even confusion prevails in related literature concerning the term's meaning and conceptualisation (Koenen, Dochy, and Berghmans 2015; Wesselink and Wals 2011. Related concepts include terms such as 'knowledge', 'skills', 'ability', 'capability', and 'expertise'. In recent times, professional 'agency' has also been seen as closely intertwined with those concepts (see Eteläpelto et al. 2013).

Mulder (2011; see also Mulder et al., 2009) has added some structure to the wide and diversified field of competence theory and research. He differentiates between the three approaches to competence. The first one, 'competence as behaviouristic functionalism', refers to 'competencies' as trainable and isolated skills and knowledge not related to occupational epistemologies. The second perspective, 'competence as integrated occupationalism', sees competence as a holistic concept that integrates factors of knowledge, skills and attitudes that are in balance together and transform those elements into an integrated personal capability to achieve results. In the third approach, 'situated professionalism', competence gets its meaning in a specific context and through interaction with other professionals; here, the theories and practices of professional development are closely related.

In recent research literature, it has been typical to see competence as a holistic concept that integrates factors of knowledge, skills and attitudes, and at the same time acknowledges the situated and contextual nature of competence

(Mulder et al., 2009). Professional competence refers to a generic, integrated and internalised capability that enables an effective performance in certain task situations, in a real performance context in the professional domain (Mulder, 2014). The development of professional competence is a long process that always requires learning as well as what Ericsson, Krampe and Tesch-Römer, Prietula and Cokely (2007 1993$)$ have called deliberate practice, that is, the intentional pursuit toward the improvement of performance. This enables an individual to work effectively in different and changing situations, and to learn and develop his or her own competence (e.g., Mulder et al., 2009; Mulder, 2011).

The development of competence has often been described as a progression through different stages from beginner to expert level (e.g., in studies on nurses: Benner 2000) or as a series transformational steps such as noted in transformative learning theories (e.g., Mezirow 1990), or as a process of integrating different forms of knowledge as proposed as part of the integrative pedagogy model (Tynjälä 2008; Tynjälä and Gijbels 2012; Tynjälä et al. 2016). A significant characteristic in competence development is the increase in workers' tacit knowledge, which is deeply related to skills and acquired mainly through practical experience (Eraut 2000).

Kommentoinut [PT2]: Vaihdoin tähän lähteen, koska tuo 2007 lähde on Harvard Business Review-lehdessä, joka taitaa olla vähän populaarimpi lehti, siinä ei näyttänyt olevan edes lähdeluetteloa. Sinänsä juttu olisi ollut ihan kelvollinen. Lisäsin tämän lähteen myös lähdeluetteloon.

Yritin myös etsiä vähän uudempaa jossa olisi ollut 'deliberate practice' otsikossa, ja löysinkin yhden mutta siinä oli jotain outoa enkä löytänyt siitä alkuperäistä versiota. Ei tuo haitanne vaikka on vähän vanha. Se on kuitenkin vähän niin kuin klassikko. 
Competence has particularly been studied in vocational education, where skills, knowledge, attitudes, environments and workplace situations are seen as part of the concept of competence (e.g. Bound and Lin 2013). Various studies have attempted to assess competence in higher education contexts; for example, in regard to newly graduated nurses' competence (Wangensteen et al. 2012), medical students' end-point competence in procedural skills (a systematic review, Morris, Gallagher, and Ridgway 2012), and problem-solving competence in case study tasks (Uys et al. 2004).

In the field of physiotherapy, the main focus of the profession is on human movement and function. Thus, professional competence has been related to practitioners' examination and assessment of patients, the provision of advice and guidance, the handling of manual therapies and therapeutic exercise, as well as to supporting clients in achieving optimal freedom of movement and the ability to function, and to promoting health and wellness using evidence-based knowledge. Having good communication skills and cultural competence as well as being able to consult other professionals are also regarded important in physiotherapy (see for example, ENPHE 2012; Larsson and Gard 2006; Lindquist, Engardt, and Richardson 2010; Thiele and Barraclough 2007; Ven and Vyt 2007; WCPT 2011; Włoszczak-Szubzda and Mirosław 2013). Furthermore, it has been emphasised that physiotherapists need to be versed in various special competencies, such as skills in chronic disease management, monitoring and making early referrals in addition to having disease-specific knowledge (Briggs et al. 2012).

Increasingly, researchers in the field of physiotherapy education and practice have begun to pay attention to the competence perspective; in other words, to how physiotherapy students acquire generic and professional skills and competence for qualification. Their studies have focused on, for example, clinical reasoning skills and manual skills (e.g., Hendrick et al. 2009; Phillips et al. 2009), competence to cure and care for patients (Dahl-Michelsen 2015), argumentation skills (Rapanta, Garcia-Mila, and Gilabert 2013), generic professional competence (Shields et al. 2013), cultural competence (Fougner and Horntvedt 2012; Wickford 2014) and interprofessional skills (e.g., Robson and Kitchen 2007).

There are only few studies that have focused on how physiotherapy students themselves view their competence. One of these few is a study by Grace and Trede (2013), who found that students understood professionalism to consist of personal characteristics and behaviours such as punctuality, effectiveness, the ability to handle difficult situations, keeping abreast of the impacts of current research on practices, and trying to advance patient-oriented care.

\section{Research context and method}

\section{Aim and research question}

The purpose of the present study is to deepen the understanding of physiotherapy students' perceptions of their profession and, more specifically, to investigate their conceptions of their own professional competence at the end of their studies. The following research question was addressed: How do graduating physiotherapy students perceive their professional competence?

\section{Participants}

The research participants $(n=33)$ were final-year physiotherapy students. At the beginning of the first year of their studies, these same students had been asked to participate in a follow-up study spanning from their first year to the end 
of their studies, and they had confirmed their willingness by giving their signed consent. Participation was voluntary and the participants were free to withdraw from the study at any time. Of the original 35 students, 33 participated in this study to the end. The students were studying at the Bachelor's degree (BA) level at a Finnish university of applied sciences. Of the 33 participants, 7 were men and 26 were women. At the end of their studies, these participants were between 22-37 years old (average $=24.7$ years $)$ and had studied $2.5-4.5$ years. The Bachelor's degree programme $(210$ credits) consisted of theory studies and practical training ( 70 credits) at the school and in clinical placements. Eight participants had partly trained or studied abroad, either as international exchange students at a university or in clinical placements.

\section{Data gathering}

The present study was conducted using the phenomenographic method. In phenomenographic research, data on individuals' conceptions and experiences are usually collected through interviews (e.g., Paakkari, Tynjälä, and Kannas 2010; Åkerlind 2008). In the present study, the data were gathered by interviewing the students during the last months of their physiotherapy studies. At the beginning of the interview, the students were asked to talk about their life and study process. The open interview approach was adopted to stimulate and encourage students to freely describe their experiences and the development of their skills and competence throughout their university education. The concept of competence was not defined for the students, but they were free to express themselves in their own terms and speak about their personal development and professional competencies on the basis of their own understanding. However, the interviewer directed the interview discussions and encouraged the students to elaborate on their views and experiences in order to ensure that the students would focus sufficiently on their professional development and competencies. Typical clarifying questions were: "Can you give an example of [...]?" or, "Could you tell me more about [...]?"

The individual interviews, which lasted from 19 to 43 minutes, were audio recorded and transcribed verbatim. The resulting data consists of 159 A4-pages. For the analysis, the sections of the interviews where students spoke about how they perceive their competence were selected. The students spoke Finnish and the quotations that we have selected were later translated into English. The first translation was undertaken by the first author and discussed with the other researchers, and finally proofread by a professional. The university granted the permission for the implementation of the study. Strict confidentiality and anonymity was ensured throughout the reporting of the results.

\section{Data analysis}

As mentioned above, this study followed the phenomenographic method, which is a data-driven analytic approach focusing on research participants' experiences, understanding or conceptions of a particular phenomenon (e.g. Marton and Booth 2009, Marton and Pong 2005; Åkerlind 2005, 2012). Previous phenomenographic studies have examined, for example, professionals' and students' conceptions of knowledge and learning (Larsson and Gard 2006; McLean, Bonda, and Nicholson 2015; Paakkari, Tynjälä, and Kannas 2010; Skøien, Vågstøl, and Raaheim 2009; Stenfors-Hayes, Hult, and Dahlgren 2013; Åkerlind 2008). In the present study, the phenomenographic method was used rather than other qualitative methods since it provides a systematic way to explore differences in students' conceptions of the nature of their physiotherapy competence and involves tools that enable elaborating the characteristics of the differences found. The participants' conceptions are illustrated in descriptive categories, which present the variation in participants' understanding of the phenomenon in question (Marton and Pong 2005; Åkerlind 2012). The categories are logically 
related to one another and organised in a hierarchical way: in other words, some conceptions can be seen as more complex and more complete than others (Marton and Pong 2005; Åkerlind 2008). The categories represent the students' understandings on a collective level (Marton and Booth 2009, 128)

The phenomenographic analysis in the present study followed the principles presented in the field's literature (e.g., Bowden 2005; Marton and Pong 2005; Åkerlind 2012), and the analytic process was carried out in two main phases by the three authors. The first phase involved identifying and describing the students' conceptions of their own competence in general terms. First of all, the first author listened to the interviews and thoroughly read the verbatim transcriptions as a whole, several times, to identify differences and similarities between the students' conceptions. Next, the conceptions that were emerged in the interviews were grouped into preliminary clusters. The first draft of qualitative categories was formed by the first author in this way. After that, all three authors together compared the preliminary categories against the data and elaborated the categories when needed. In the second phase of the process, the structural relationships between the descriptive categories were examined. In other words, the themes of variation (aspects differentiating the categories) were identified and some last modifications were made. At the end of the analytic process, the descriptions of the qualitative categories of students' conceptions of their own competence were developed and agreed on by the three researchers.

\section{Results}

Graduating physiotherapy students' conceptions of their own competence were divided into four descriptive categories: 1) mastering core skills; 2) understanding the theoretical basis of physiotherapy; 3) having a holistic view of physiotherapy; and 4) engaging in and developing multi-professional collaboration (Table 1). The formed categories can be seen to be hierarchically structured, so that the categories on the right side of Table 1 represent a more complex conception of competence than the categories on the left side of the table. In addition, categories II to IV may include aspects from the categories on their left, but not vice versa. Regarding the aspects distinguishing between the categories, the themes of variation were named as follows: nature of competence, communication, knowledge acquisition, focus of reflection, emotions, cultural awareness, and professional agency (Table 1). Each of the four competence categories is described in more detail below. The themes of variation are written in italics where mentioned for the first time in a category. Excerpts from relevant interviews are included to illustrate the key aspects of the four categories, citing responses from both female (F) and male (M) participants.

[Table 1 near here]

\section{Category I: Mastering Core Skills}

In the first category, competence was seen as the mastering of core skills in the field of physiotherapy. The first identified theme of variation was the nature of competence, which in this category consists of individual skills related to the assessment of patients, manual therapy, therapeutic exercise and instruction skills. The students described, for example, skills for planning and organising patients' physiotherapy. The second theme of variation, communication, focused on students' own way of interviewing patients; in other words, the students were not completely aware of the different kinds of mechanisms involved in interacting with patients but were more focused on their own speaking. In this category, the third theme, knowledge acquisition, was related to the physiotherapist familiarising him- or herself 
with the patient data by putting active personal effort into data searching; accordingly, skills in reading, writing and understanding patient documentation were seen to be important. Regarding focus of reflection, the students paid attention to their own actions and skills, evaluating their own activities in order to recognise their faults. As for the next theme, emotions, the physiotherapy students in this category expressed mainly negative feelings such as the fear of themselves or their family members losing the ability to walk or the fear of meeting sick patients or experiencing disappointment or frustration because of patients' difficulties with training activities.

The theme of variation identified as cultural awareness was related to knowing other cultures and learning new languages. In this category, cultural awareness was expressed as being able to communicate with foreigners using at least some basic words with patients and their relatives and being able to instruct foreign patients in physiotherapeutic self-treatments and therapeutic exercises. The theme of variation called professional agency refers to individuals' way of making choices, taking stances regarding their work and having influence over their work. In this category, professional agency appeared to be focused on the development of students' own skills and on growing as a person. For example, students described that as a result of their studies they had started to increasingly value their own life and began to change their lifestyle to include more exercise and healthy habits. These students also realised that their manual skills were poor and that they needed more practice to develop them.

The view of competence as mastering core skills often emerged in students' statements describing their own individual skills, actions and development, as well as regard to their negative emotions, their own way of communicating, the importance of understanding patient data and knowing other cultures, and focusing on their skill development and growing as a person. These points are illustrated in the following quotes (with the source code shown in parentheses following each excerpt):

My interview skills are well developed and I can learn step by step what I have to take into account when planning physiotherapy with patients. (M1)

The most serious thing that could happen would be that I or a family member loses the ability to walk, or contracts a serious illness. (F4)

I learned a lot about new cultures and I learned a new language, Swahili - at least some basic words to communicate with and instruct patients. (F5)

My own life has changed; I exercise and consider my health more; I have more awareness of my body and feelings. (F28)

\section{Category II: Understanding the Theoretical Basis of Physiotherapy}

In line with the phenomenographic research principles, students' understanding and experiences of competence expanded from one category to the next. Accordingly, in the second category, students did not experience the nature of competence merely as separate skills and were also considering the theoretical basis of different skills. Thus, physiotherapy competence was seen as understanding the theoretical basis of physiotherapy. In these students' view, 
theoretical fundamentals such as anatomy, biomechanics, physiology, physiological exercise, motor skills and knowledge of exercise were seen to be particularly relevant for physiotherapy. Understanding patients' communication was seen to be important in this category. Communication was also seen as a means to justify treatments, correct patients' knowledge and motivate them by using theoretical arguments. As for the next theme, knowledge acquisition, in this category students were searching for evidence-based data to support physiotherapy planning.

In this second category, the focus of reflection expanded from the students' own skills and actions, now also including considerations regarding their interaction with patients. The students felt that self-reflection helped them to deduct, solve problems and make decisions in patient situations. Regarding emotions, positive experiences dominated and students expressed that they are able to cope with their emotions, control their own feelings and fears, and that they have developed a lot of awareness of their own body and feelings. The students still found new situations and challenges emotionally heavy or worrying but also rewarding. As for the next theme, cultural awareness, in this category the students compared other cultures' physiotherapy treatments to Finnish ones. In these students' view, different cultures use different approaches to treating patients and the theoretical bases of some treatments differed; for example, treatments to reduce swelling caused by an operation. Students' professional agency covered patients' therapy; the students felt that they have strong and wide-ranging theoretical knowledge and the ability to apply it in physiotherapy practice, although they seemed to need more practical training in applying theory to practice. The following quotations illustrate the views belonging to the second category:

In order to ensure that my tests and assessments will be reliable and objective enough I practice patient examination and use specific assessment tests. (F9)

I am client centered, and I feel that communication and creating a trusting relationship is easy for me. I also feel that I'm quite skillful in kind of 'selling' something. For example I had a patient who used to be a doctor, and this old doctor said that when he swallows food lodges itself on musculus piriformis. But this muscle is on the buttock! So, I just ignored it and we started with another topic. (F9)

[Physiotherapy involves] critical reflection on risk factors characteristic of patients; for example, an overload in the articulation of the muscles and also malpositioning. (M26)

A feeling of inadequacy took over when treating mentally disabled patients, but it was very rewarding [as a learning experience]. (F29)

A client asked why she can't lift up her arm even though she doesn't feel pain. I had to begin with the basics, from the cell level, and explain that the fracture can't bear any weight; I had to explain the reasons. (F23)

\section{Category III: Having a Holistic View of Physiotherapy}

In the third category, competence was seen as taking a holistic approach to physiotherapy. The students expressing this view experienced the nature of competence as an integrated entity. In other words, they felt that the human body is a complicated whole where everything interacts and affects everything else, such as the physical, social and 
psychological aspects of functioning as well as psychic and mental elements. Holistic approach was seen to be important and the key point in physiotherapy. The students described, for example, skills to observe, plan and treat patients using complicated processes, the competence to assess patients' development and progress, and the effectiveness of treatments. The second theme, communication, expanded from understanding patients' communication to co-operation with patients and their relatives. Establishing a proper emotional atmosphere and gaining the confidence of the patient were experienced to be relevant when aiming at patients' successful commitment to physiotherapy.

Noticing a patient's life crisis, or calming a broken-hearted patient, or communicating nonverbally and verbally in order to gain an understanding of an ALS (amyotrophic lateral sclerosis) patient's neurological state were examples of this kind of communication.

Regarding knowledge acquisition students emphasised evidence-based research, theory and current care guidelines (evidence-based clinical practice guidelines), which they were acquiring in an active and critical way. This active, systematic and broadened search for theoretical knowledge based on evidence was seen to enhance students' holistic view of physiotherapy and their holistic professional competence.

As for the next theme, focus of reflection, the students paid attention to the whole physiotherapy process. In other words, students' reflection was critical and helped them to plan a more effective therapy process in co-operation with their patients, to change goals when patients' physical or psychic function changed, and to choose relevant and innovative combinations among the physiotherapy treatment options. In this category, emotions were not only coped with but approached with a professional attitude so that these students were able to bracket their negative feelings while handling their patients and deal with their own emotions afterward. Students expressed that they are able to cope and work with different kinds of very ill or demanding patients and that they appreciate even small achievements.

Regarding cultural awareness, students' conceptions of how the cultural dimension is relevant to physiotherapy further broadened. The students compared Finnish physiotherapy and the Finnish way of communicating with patients to the approaches taken in other cultures. Students described, for example, that in Kenya the whole family gets involved in physiotherapy treatment sessions, helping the patient with the therapeutic exercises according to the physiotherapy student's instruction, or that in some countries small villages are so poor that they do not even have walking aids available and that the student actually built the physiotherapy device with the physiotherapist.

The theme of variation labelled professional agency reflected active agency more so than in the previous categories that focused on evaluating and developing physiotherapy practices. Here, the students were also more concerned with ethical principles, and they were interested in evaluating and developing such principles. They felt more competent and motivated, and their development was more intentional.

The view of competence entailing the development of a holistic view of physiotherapy often appeared in expressions describing competence in association with integrated competence, co-operation, evidence-based data, professional attitude, the physiotherapy process as a whole, the widening of one's own cultural conceptions relating to physiotherapy, and the evaluating and developing of physiotherapy practices incorporating ethical considerations. These points are illustrated in the following quotes:

I consider patients' life situations and motivation, and their social, psychological, psychic and mental resources. (M1)

I actively and critically search for evidence-based data and conduct research on what kinds of treatments are most likely to be effective; I feel that I can help to heal patients' suffering. (F10) 
I noticed and could follow patients' progress throughout the training period, particularly when comparing the assessment of the treated function at the end of the treatment with that at the beginning. (F27)

I compare physiotherapy communication and treatment sessions in Finland to those in Taipei. (M21)

To modernise the old traditions of patient treatment, more effective methods need to be developed. (F24)

\section{Category IV: Engaging in and Developing Multi-Professional Collaboration}

In the fourth category, which is the final and most advanced as well as complex of the four categories, students understood and experienced competence as developing multi-professional, collaborative work skills. The first theme of variation, the nature of competence, expanded here to a kind of boundary-crossing competence. Students expressed that they possess the competence to plan and instruct patients and athletes in collaboration with other professionals from different organisations and societies.

As for next theme, communication, the students' co-operation broadened to involve multi-professional collaboration. Students described multi-professional teamwork with nurses, doctors, insurance companies and coaches. In this fourth category, knowledge acquisition was seen to enhance multi-professional collaboration skills through participation in multi-professional documentation and conducting different kinds of evidence-based, research, for example.

The focus of reflection expanded to involve reflecting on multi-professional rehabilitation programmes and organisations. Students reflected critically and attention was paid to the whole physiotherapy process. The students still found reflection challenging because every organisation has its own treatment tradition. As for the next theme, dealing with emotions, students described a similar professional way of dealing with emotionally challenging situations as the students in the previous category, but now adding an aspect of collaboration. Thus, their individual emotional work expanded to collaborative activity where they discussed their feelings and emotions with their peer students, colleagues and other professionals, from whom students also gained a lot of positive feedback. These students seemed to be particularly concerned with their patients' well-being and the patients' ability to cope in difficult situations.

Regarding cultural awareness, the students ruminated over different social and health care approaches. These students were comparing, for example, the roles of patients in Finnish and other cultures regarding care, treatments, hospitals and societies, and they noticed that they differ from each other. The theme of professional agency expanded and diversified to include evaluating different social and health care systems as well as guidelines for treating different diseases. The examples below illustrate the views of students in the fourth category:

Getting in touch with KELA (Kansaneläkelaitos; independent social insurance institution supervised by Finnish parliament) and other insurance companies, for example, and writing expert reports for them, reading up on doctors' medical referrals for physiotherapy, rehabilitation [and so on]; these represent different kinds of multi-professional work and collaboration with other professionals. (F9)

I wanted to learn more from and be challenged by other colleagues, it was not easy to actively practice critical 
reflection on other physiotherapists' work or training, for example, in regard to evaluating patients' spasticity [...] all organisations have their own customs or traditional treatment methods. (F29)

In large social and health care service organisations, such as central hospitals, they have their own social and health care service systems and they plan and update their own guidance paths and current care guidelines, including rehabilitation guidelines for different diseases. (M1)

\section{Discussion}

While previous literature on professional competence has focused on clarifying the concept of competence in general (e.g., Mulder, 2011), or on describing physiotherapy lecturers' and students' understandings of professionalism in their field in particular (Grace and Trede 2013), our study directly examined how graduating physiotherapy students described their own professional competence. It is important to investigate students' conceptions of competence to see whether there are gaps between graduates' views and the goals of education. The added value of our phenomenographic approach is that the findings concretely show that there is large variation in graduating physiotherapy students' understanding of their competences, and they reveal the critical aspects that need to be considered in order to support students in developing their understanding from less advanced toward more advanced conceptions. In our study, physiotherapy students' conceptions of their physiotherapy competence at the end of their studies could be divided into four descriptive categories: 1) mastering core skills; 2) understanding the theoretical basis of physiotherapy; 3) having a holistic view of physiotherapy; and 4) engaging in and developing multi-professional collaboration. The first category represents the simplest conception, while the fourth represents the most complex and developed one. The categories varied hierarchically on the basis of seven themes: skills, communication, knowledge acquisition, focus of reflection, emotions, cultural awareness and professional agency (Table 1).

In combination with previous knowledge on physiotherapy education, the findings of the present study can be used as a tool for developing pedagogical practices in physiotherapy education to transform students' competences and professionalism. Below, we discuss the implications of the study for educational and pedagogical planning as well as for practices in the field of physiotherapy and possibly other fields. From a pedagogical point of view, four critical aspects can be identified as categories: Focus of reflection, Professional agency, Cultural awareness, and Communication. These aspects are critical from the perspective of supporting students to understand professional competence in a broader sense.

The focus of reflection expanded from physiotherapy students' own skills and actions in category I to the interaction with patients in category II, and developed further to include the whole physiotherapy process as well as multiprofessional collaboration with various organisations and rehabilitation professionals in categories III and IV. From a pedagogical point of view, the interesting question is what kind pedagogical practices can promote this kind of expansion in the focus of reflection. Some studies suggest that conversations with different professionals and reflective writing tasks develop physiotherapy students' reflection skills (e.g. Hendrick et al. 2009; Kurunsaari, Tynjälä, and Piirainen 2015; Lindquist et al. 2006). Thus, in order to bring about development in the focus of reflection, it is important to guide students' reflection with learning tasks that support reflection on different foci. Timely feedback from a tutor to facilitate physiotherapy students' learning (Francis-Coad and Hill 2014) is also valuable. All in all, our findings suggest that reflecting both at the individual and collective level can transform a student's professional 
competence. Similarly, Grace and Trede (2013) found that students' self-awareness and articulation regarding their own values may develop their professionalism through learning by doing.

The second pedagogically critical aspect, professional agency, expanded in a similar way as the focus of reflection, that is, from individual aspects of professional competence toward reflection on and participation in social and systemwide practices. This kind of transformation can be induced by providing students with opportunities for collaboration and multi-professional work, such as with doctors and nurses. It is interesting that in a previous study by Grace and

Trede (2013), physiotherapy students' understandings of professionalism did not include multidisciplinary teamwork or preventive health care, whereas, in our study, these came up as important elements in Finnish students' conceptions of professional competence. This probably reflects the Finnish health care system, which emphasises multiprofessional preventive work and counselling in health care and in physiotherapy in a way that is quite unique in the world. Previous studies have also suggested that interprofessional learning is effective in improving student physiotherapists' awareness of role issues and the ability to develop collaborative work relationships (see Davies et al., 2012). In supporting a multiprofessional approach to working among students, clinical placements play a crucial role. These types of placements have also been found to be central to providing quality in learning achievement, such as in developing a sense of trust and a balance between being supported and challenged (Vågstol and Skoien 2011), and has also been emphasised in Mulder's (2011) situated professionalism perspective. Furthermore, work relationships, as well as the quality of guidance given by clinical educators, can contribute to a positive learning environment for physiotherapy students to develop their own learning in workplaces (Patton, Higgs, and Smith 2013), and also for clinical instructors and role models to influence students in evidence-based practice (Olsen et al., 2013), as seen in our study. All of this supports Mulder's situated professionalism perspective. Thus, clinical educators should be encouraged to facilitate students' active participation in a workplace, due to its critical contribution to student learning (Virtanen, Tynjälä, and Eteläpelto, 2014).

The third critical pedagogical aspect in our findings is the role of communication. Earlier studies have shown that versatile communication skills are important in physiotherapy (for example, see Hiller, Guillemin, and Delany, 2015). In our study, experiences of understanding patient communication clearly emerged within category II, where the students expressed experiences of having the ability to respect all patients and the 'know-how' to co-operate and communicate effectively, and feeling able to cope with challenging situations and to win patients' confidence. These students used theoretical arguments to justify treatments, to motivate patients and to correct patients' knowledge (cf. Rapanta, Garcia-Mila, and Gilabert 2013). Skills like having an empathic understanding of patients and respecting patients' feelings, sensations and individual life situations, as well as having an informed understanding of disabilities has seen as essential for physiotherapy students to develop. Similar findings have appeared in numerous other studies as well (cf. Shields et al. 2013; Włoszczak-Szubzda and Mirosław 2013). In this regard, for example, training with simulated patient interaction may reduce students' anxiety and increase confidence in communicating with different kinds of patients (Lewis et al. 2013; Dandridge et al. 2014). Further, communication skill development requires adequate learning time (Parry and Brown 2009) and timely feedback from a tutor in practical training (Francis-Coad and Hill 2014). The learning context and with whom students are learning is generally important (Lindquist, Engardt, and Richardson 2010).

In times of globalisation, internalisation and increasing immigration, we can regard cultural awareness as the fourth critical pedagogical aspect in our findings. In the earlier mentioned Australian study (Grace and Trede 2013), cultural competence was not part of physiotherapy students' understanding of professionalism, whereas in our research for the 
present study this aspect clearly came up in students' experiences. Developing awareness of other cultures by training in a multicultural environment or by studying abroad through international exchange programmes at foreign universities or in clinical placements is recommended for Finnish physiotherapy education. Pedagogically, it is important that students gain a broad understanding of cultural differences and are able to compare their own circumstances with those of clients from other cultures. Our findings suggest that studying other cultures in one way or in another broadens one's conception of physiotherapy, and learning in diverse contexts prevents confrontations and misunderstandings based on myths and stereotypes (also found in other studies e.g., Fougner and Horntvedt 2012; Mostert-Wentzel, Frantz, and van Rooijen 2013; Wickford 2014). Cultural awareness can be supported during professional studies by including teachings about other cultures in the curriculum, by participating in practical training in different countries, by studying in multinational groups, by participating in intensive multicultural courses such as in summer school, and by systematically reflecting on one's own experiences.

Altogether, the four pedagogically critical aspects described above show the focal points in students' progression from one category to the next regarding their conception of competence. First, we recommend supporting students' reflection during physiotherapy studies, or in any higher education studies, so that the focus of reflection gradually moves from personal and individual issues toward social and societal spheres, as this is a key to the development toward a socially responsible professional. Second, paying attention to the ways of communication and the development of communication skills seems to support the move from individualistic reflection toward social responsibility. Third, our findings imply that supporting the development of students' professional agency, especially in workplaces that provide multiprofessional opportunities, is of crucial importance. Finally, the findings highlight the importance of developing cultural awareness in our multicultural world.

The main limitation of this study is typical for qualitative research, that is, the small sample; although, a whole group of physiotherapy students was examined. At the same time, the advantage of this is that a small data set makes it possible to go deeper in order to understand a phenomenon better. In fact, some phenomenographic studies have found that the saturation point can be as small as 11 participants (Mason 2010; Täks 2015, 48-49). Another limitation, related to the previous one, is the fact that the research was conducted in only one discipline. However, we believe that the findings about physiotherapy students'conceptions of their own competence can also be of relevance to other fields of higher education.

\section{Acknowledgements}

The authors sincerely thank all of the physiotherapy students who participated in this study.

\section{References}

Achcaoucaou, F., L. Guitart-Tarrés, P. Miravitlles-Matamoros, A. Núñez-Carballosa, M. Bernardo, and A. Bikfalvi. (2014). Competence Assessment in Higher Education: A Dynamic Approach. Human Factors and Ergonomics in Manufacturing \& Service Industries 24, no.4: 454-467. AHELO. (2013). The OECD’s Assessment of Higher Education Learning Outcomes.

http://www.oecd.org/site/ahelo.

Åkerlind, G. (2005). Learning about phenomenography: Interviewing, data analysis and qualitative research paradigm. In J.D. Bowden \& P. Green (Eds.) Doing developmental phenomenography
Kommentoinut [PT3]: Tämä tarkoittaa sitä että me suosittelemme harjoittelupaikkoja suomalaiselle fysioterapriakoulutukselle. Oliko tarkoitus kuitenkin todeta että fysioterapriakoulutukselle. Olko tarkoitus kuitenkin todeta suomalaisessa fysioterapiakoulutuksessa suositellaan kansainvälist harjoittelua yms? Jos tämä on tarkoitus niin tämä pitäisi muuttaa: $\ldots$.. is recommendad IN THE GUIDELINES OF FINNISH ... TAI
JOTAIN MUUTA VASTAAVAA. Jos on joku kirjallisnen ohjeistus siitä pitäisi oikeastaan olla myös lähdekin. 
63-78. Melbourne: RMIT University Press.

Åkerlind, G. 2008. A phenomenographic approach to developing academics' understanding of the nature of teaching and learning. Teaching in Higher education 13, no.6: 633-644.

Åkerlind, G. 2012. Variation and commonality in phenomenographic research methods. Higher

Education Research \& Development 31, no. 1, 115-127.

Benner, P. 2000. The Wisdom of Our Practice. American Journal of Nursing 100, no.10: 99-105.

Bergsmann, E., M-T. Schultes, P. Winter, B. Schober, and C. Spiel. 2015. Evaluation of competence-based teaching in higher education: From theory to practice. Evaluation and

Program Planning 52: 1-92.

Bound, H., and M. Lin. 2013. Developing Competence at Work. Vocations and Learning 6: 403 420.

Bound, H., and S. Stack. 2012. Tools for Learning Design. Research Project. Exploring new approaches to professional learning: Deepening pedagogical understanding of Singapore CET trainers through meta-cognition and practitionerbased research. Singapore: IAL.

Bowden, J. 2005. Reflections on the phenomenographic team research process. In J. A. Bowden \&

P. Green (Eds.) Doing developmental phenomenography, 11-31. Melbourne: RMIT University

Press.

Briggs, R., R. Fary, H. Slater, P. Bragge, J. Chua, H. Keen, and M. Chan. 2012. Disease-Specific Knowledge and Clinical Skills Required by Community-Based Physiotherapists to Co-Manage Patients with Rheumatoid Arthritis. Arthritis Care \& Research 64, no. 10: 1514-1526.

Dahl-Michelsen T. 2015. Curing and caring competences in the skills training of physiotherapy students. Physiotherapy Theory and Practice 31, no. 1: 8-16.

Dandridge, T., B. Stubbs, C. Roskell, and A. Soundy. 2014. A survey of physiotherapy students' experiences and attitudes towards treating individuals with mental illness. International Journal of Therapy and Rehabilitation 21, no. 7: 324-330.

Davies. K., K. Harrison, D.L. Clouder, M. Gilchrist, L. McFarland, and J. Earland. 2011. Making the transition from physiotherapy student to interprofessional team member. Physiotherapy 97 : $139-144$.

ENPHE. 2012. The final outcome of Quality Assurance: Introducing and promoting quality in physiotherapy in higher education in Europe. http://enphe.org/Portals/enphe/documents/Poster\%20Quality\%20Focus\%20Group\%20Report.pdf. EQF. 2008. The European Qualifications Framework 2008.

http://ec.europa.eu/education/lifelong-learning-policy/doc44 en.htm.

Eraut, M. 2004. Transfer of knowledge between education and workplace settings. In H. Rainhbird,

A. $\Lambda$.Fuller, and A. Munro (Eds.). Workplace learning in context, 201-221. London: Routledge.

Ericsson, K.A., Krampe, R.Th., and Tesch-Römer, C. 1993. The role of deliberate practice in the acquisition of expert performance. Psychological Review 100: 363-406.

Eteläpelto, A., K, Vähänsantanen, K.Hokka, and S. Paloniemi. 2013. What is agency?

Conceptualizing professional agency at work. Educational Research Review 10: 45-65.

European Commission. 2014. The Bologna process and the European higher education area.

\begin{tabular}{l|}
\hline Muotoiltu: Fontti: $10 \mathrm{pt}$ \\
\hline Muotoiltu: englanti (Yhdysvallat) \\
\hline Muotoiltu: Fontti: $10 \mathrm{pt}$ \\
\hline Muotoiltu: Luettelokappale, Automaattinen numerointi + \\
Taso: $1+$ Numerointityyli: A, B, C, $\ldots+$ Aloittava nro: $1+$ \\
Tasaus:Vasen + Tasaa: $0,34 \mathrm{~cm}+$ Sisennä: $0,98 \mathrm{~cm}$ \\
\hline Muotoiltu: Sisennys:Vasen: $0 \mathrm{~cm}$, Riippuva: $0,5 \mathrm{~cm}$ \\
\hline Muotoiltu: Fontti: Kursivoitu \\
\hline Muotoiltu: englanti (Yhdysvallat) \\
\hline Muotoiltu: suomi \\
\hline
\end{tabular}


http://ec.europa.eu/education/policy/higher-education/bologna-process_en.htm.

Fougner M., and T. Horntvedt. 2012. Perceptions of Norwegian physiotherapy students: Cultural diversity in practice. Physiotherapy Theory and Practice 28, no.1: 18-25.

Francis-Coad, J., and A-M. Hill. 2014. Discovering What Experiences Physical Therapist Students Identify as Learning Facilitators in Practical Laboratories. Journal of Physical Therapy

Education 28, no. 3: 424-449.

Grace, S., and F. Trede. 2013. Developing professionalism in physiotherapy and dietetics students in professional entry courses. Studies in Higher Education 38, no. 6: 793-806.

Hendrick P., C. Bond, E. Duncan, and L. Hale. 2009. Clinical reasoning in musculoskeletal practice: Students conceptualizations. Physical Therapy 89: no.5: 430-442.

Hiller, A., M. Guillemina, and C. Delany. 2015. Exploring healthcare communication models in private physiotherapy practice. Patient Education and Counseling 98: 1222-1228.

Khaled, A, J. Gulikers, H. Tobi, H. Biemans, C. Oonk, and M. Mulder. 2014. Exploring the Validity and Robustness of a Competency Self-Report Instrument for Vocational and Higher Competence-Based Education. Journal of Psychoeducational Assessment, 32, no.5: 429-440.

King, A. 1993. From sage on the stage to guide on the side. College Teaching, 41: 30-35.

Koenen A-K., F. Dochy, and I. Berghmans. 2015. A phenomenographic analysis of the implementation of competence based education in higher education Teaching and Teacher Education 50, no.1:12.

Kurunsaari, M., P. Tynjälä, and A. Piirainen. 2015. Students' Experiences of Reflective Writing as a Tool for Learning in Physiotherapy Education. In G. Ortoleva, M. Bétrancourt, \& S. Billet (Eds.), Writing for professional development. Studies in Writing, Volume 32. Language \& Linguistics (pp. 129-151).

Larsson I. and G. Gard. 2006. Conceptions of physiotherapy knowledge among Swedish physiotherapists: a phenomenographic study. Physiotherapy 92: 110-115.

Lindquist I., M Engardt, L. Garnham, F. Poland, and B. Richardson. 2006. Development pathways in learning to be a physiotherapist. Physiotherapy Research International 11, no 3:129-139.

Lindquist, I., M. Engardt, and B. Richardson 2010.Learning to be a Physiotherapist: A Metasynthesis of Qualitative Studies. Physiotherapy Research International 15, no 2: 103-110. Marton, F., and S. Booth. 2009. Learning and awareness. Hillsdale, NJ: Lawrence Erlbaum. Marton, F., and W.Y Pong. 2005. On the unit of description in phenomenography. Higher Education Research and Development 24: 4: 335-348.

Mason, M. 2010. Sample Size and Saturation in PhD Studies Using Qualitative Interviews.

Qualitative Social Research 11, no 3. http://www.qualitative-research.net/index.php/fqs/index.

McLean, A., C. Bonda, and H. Nicholson. 2015. An anatomy of feedback: a phenomenographic investigation of undergraduate students' conceptions of feedback. Studies in Higher Education 40, no. 5: 921-932.

Mezirow, J. 1990. Fostering critical reflection in adulthood: a guide to transformative and emancipatory learning. San Francisco (California): Jossey-Bass.

Morris, M., T. Gallagher, and P. Ridgway. 2012. Tools used to assess medical students' competence in procedural skills at the end of a primary medical degree: a systematic review. 
Medical Education. http://dx.doi.org/10.3402/meo.v17i0.18398.

Mostert-Wentzel, K., J. Frantz, and AJ. van Rooijen .2013. A model for community physiotherapy from the perspective of newly graduated physiotherapists as a guide to curriculum revision $A J H P E, 5,1$.

Mulder, M. 2011. The concept of competence: Blessing or curse? I. Torniainen, S. Mahlamäki-Kultanen, P. Nokelainen and P. Ilsley (Eds). Innovations for Competence Management. Conference Proceedings, 11-24. Lahti: Lahti University of Applied Sciences.

Mulder, M. 2012. Competence-based education and training. The Journal of Agricultural Education and Extension 18 , no. 3: 305-314.

Mulder, M. 2014. Conceptions of Professional Competence. In S. Billett, C. Harteis, H. Gruber (Eds). International Handbook of Research in Professional and Practice-Based Learning, 107-137. Dordrecht: Springer.

Mulder, M., J. Gulikers, H. Biemans, and R. Wesselink. 2009. The new competence concept in higher education: Error or enrichment? Journal of European Industrial Training 33, no. 8/9: 755-770.

Mulder, R. 2013. Exploring feedback incidents, their characteristics and the informal learning activities that emanate from them. European Journal of Training and Development 37, no. 1: 49-71.

Nicoll, K .and H. Salling Olesen. 2013. Editorial: What's new in a new competence regime? In This issue: What's new in a new competence regime? RELA. European Journal for Research on the Education and Learning of Adults, 4, no. 2: 103-109.

Olsen, N., P. Bradley, K. Lomborg, and M. Nortvedt. 2013. Evidence-based practice in clinical physiotherapy education: A qualitative interpretive description. BMC Medical Education 13:52, 1-14.

Organisation for Economic Co-operation and Development. 2014. Education. http://www.oecd.org/education/.

Paakkari, L., P. Tynjälä, and L. Kannas. 2010. Student teachers' ways of experiencing the teaching of health education. Studies in Higher Education 35, no. 8: 905-920.

Parry, R., and K. Brown. 2009. Teaching and learning communication skills in physiotherapy: What is done and how should it be done? Physiotherapy 95: 294-301.

Patton, N., J. Higgs, and M. Smith. 2013. Using theories of learning in workplaces to enhance physiotherapy clinical education. Physiotherapy Theory and Practice 29, no. 7: 493-503.

Phillips, D., S. Barnard, M. Mullee, and M. Hurley. 2009. Simple anatomical information improves the accuracy of location specific spinous processes during manual examination of the low back. Manual Therapy 14: 346-350.

Rapanta, C., M. Garcia-Mila, M. and Gilabert, S. 2013. What Is Meant by Argumentative Competence? An Integrative Review of Methods of Analysis and Assessment in Education. Review of Educational Research no. 4: 483-520.

Robson M., and S. Kitchen. 2007. Exploring physiotherapy students' experiences of interprofessional collaboration in the clinical setting: A critical incident study. Journal of Interprofessional Care, 21, no.1: 95-09.

Schneckenberg, D., U. Ehlers, and H. Adelsberger. 2011. Web 2.0 and competence-oriented design of learning-Potentials and implications for higher education. British Journal of Educational Technology 4, no. 5: 747-762. 
Shields N., A. Bruder, N. Taylor, and T. Angelo. 2013. Getting fit for practice: An innovative paediatric clinical placement provided physiotherapy students opportunities for skill development. Physiotherapy 99: 159-164.

Skøien A.K., U. Vågstøl, and A. Raaheim. 2009. Learning physiotherapy in clinical practice: student interaction in a professional context. Physiotherapy Theory and Practice 25, no.4: 268278 .

Stenfors-Hayes, T., H. Hult, and M. Dahlgren. 2013. A phenomenographic approach to research in medical education. Medical Education 47: 261-270.

Struyven, K., and M. De Meyst. 2010. Competence-based teacher education: Illusion or reality? An assessment of the implementation status in Flanders from teachers' and students' points of view. Teaching and Teacher Education 26, no 8: 1495-1510.

Täks, M. 2015. Engineering students' experiences of entrepreneurship education. A qualitative approach Institute of Education, Faculty of Social Sciences and Education, University of Tartu, Estonia.

Thiele. A., and A. Barraclough. 2007. Journal of Physical Therapy Education 21, no. 3: 47-52.

Tremblay, K., D. Lalancette, D. and D. Roseveare. 2012. Assessment of higher education learning outcomes. AHELO. Feasibility Study Report. Volume 1. OECD.

Tuxworth, E. 1989. Competence-based education and training: Background and origins. In J. Burke (Eds.) Competency-Based Education and Training, 10-25. London: The Falmer Press.

Tynjälä, P. 2008. Perspectives into Learning at the Workplace. Educational Research Review 3, 130-154

Tynjälä, P., and D. Gijbels. 2012. Changing world - Changing pedagogy. In P. Tynjälä, M-L.

Stenström\& M. Saarnivaara (Eds.) Transitions and transformations in learning and education,

205-222. Dordrecht: Springer.

Tynjälä, P., Virtanen, A., Klemola, U., Kostiainen, E., \& Rasku-Puttonen, H. (2016). Developing social competence and other generic skills in teacher education : applying the model of integrative pedagogy. European Journal of

Teacher Education, 39 (3), 368-387. doi:10.1080/02619768.2016.1171314

Uys, L., L. van Rhyn, N. Gwele, P. Mcinerney, and T. Tanga. 2004. Problem-solving competency of nursing graduates. Journal of Advanced Nursing 48, no. 5: 500-509.

Ven. A., and A. Vyt. 2007. The Competence Chart of the European Network of Physiotherapy in Higher Education. Antwerp-Apeldoorn: Garant.

¿Virtanen, A., Tynjälä, P. \& Eteläpelto, A. 2014. Factors promoting vocational students’ learning at work: Study on student experiences. Journal of Education and Work, 27: 43-70.

Vågstol U., and A. Skoien. 2011. "A learning climate for discovery and awareness": Physiotherapy students' perspective on learning and supervision in practice. Advances in Physiotherapy 13: 7178.

Wangensteen, S., I. Johansson, M. Björkström, and G. Nordström. 2012. Newly graduated nurses' perception of competence and possible predictors: A cross-sectional survey Journal of Professional Nursing 28, no. 3: 170-181.

WCPT. 2011. World Confederation for Physical Therapy. WCPT guideline for physical therapist professional entry level education. London, UK: WCPT Policy statement: Education.

\begin{tabular}{|l|}
\hline Muotoiltu: Fontti: $10 \mathrm{pt}$ \\
\hline Muotoiltu: Sisennys:Vasen: $0 \mathrm{~cm}$, Riippuva: $0,4 \mathrm{~cm}$ \\
\hline Muotoiltu: Fontti: $10 \mathrm{pt}$, Kursivoitu \\
\hline Muotoiltu: Fontti: $10 \mathrm{pt}$ \\
\hline Muotoiltu: Fontti: $10 \mathrm{pt}$ \\
\hline
\end{tabular}


http://www.wcpt.org/sites/wcpt.org/files/files/PS Education_Sept2011.pdf

Wesselink, R., A. Dekker-Groen, H. Biemans, and M. Mulder. 2010. Using an instrument to analyse competence-based study programmes: experiences of teachers in Dutch vocational education and training. Journal curriculum studies 42, no. 6: 813-829.

Wesselink, R., and A. Wals, 2011. Developing competence profiles for educators in environmental education organisations in the Netherlands. Environmental Educational Research, 17, no.1: 6990.

Wickford, J. 2014. Conscious seeing: A description of a reflective framework used with final-year Swedish physiotherapy students in the context of international clinical placements. European Journal of Physiotherapy 16: 41-48.

Włoszczak-Szubzda, A, and J. Mirosław. 2013. Professional communication competences of physiotherapists - practice and educational perspectives. Annals of Agricultural and Environmental Medicine 20, no.1: 189-194.

Yanua, C., and R. Watson. 2011. A review of clinical competence assessment in nursing. Nurse Education Today, 31: 832-836. 
THEMES OF

VARIATION

CATEGORIES

Physiotherapy

Competence as:

Table 1. Graduating Physiotherapy Students' Conceptions of Their Own Competence 


$\begin{array}{llll}\text { I. Mastering Core } & \text { II. Understanding the } & \text { III. Having a Holistic } & \text { IV. Engaging in and } \\ \text { Skills } & \text { Theoretical Basis of } & \text { View of Physiotherapy } & \begin{array}{l}\text { Developing Multi- } \\ \text { Physiotherapy }\end{array} \\ & & & \text { Coflabsional } \\ & & \end{array}$

\begin{tabular}{|c|c|c|c|c|}
\hline $\begin{array}{l}\text { Nature of } \\
\text { competence }\end{array}$ & Individual skills & $\begin{array}{l}\text { Theoretical bases for } \\
\text { different skills }\end{array}$ & Integrated competence & $\begin{array}{l}\text { Boundary-crossing } \\
\text { competence }\end{array}$ \\
\hline $\begin{array}{l}\text { Communicati } \\
\text { on }\end{array}$ & $\begin{array}{l}\text { My way to } \\
\text { communicate }\end{array}$ & $\begin{array}{l}\text { Understanding } \\
\text { patients' } \\
\text { communication }\end{array}$ & Co-operation & $\begin{array}{l}\text { Multi-professional } \\
\text { collaboration }\end{array}$ \\
\hline $\begin{array}{l}\text { Knowledge } \\
\text { acquisition }\end{array}$ & Patient data & $\begin{array}{l}\text { Evidence-based data } \\
\text { (for patients' } \\
\text { physiotherapy) }\end{array}$ & $\begin{array}{l}\text { Evidence-based data } \\
\text { for developing } \\
\text { professional PT }\end{array}$ & $\begin{array}{l}\text { Evidence-based data } \\
\text { for multi-professional } \\
\text { collaboration }\end{array}$ \\
\hline $\begin{array}{l}\text { Focus of } \\
\text { reflection }\end{array}$ & Own skills and actions & $\begin{array}{l}\text { Interaction with } \\
\text { patients }\end{array}$ & $\begin{array}{l}\text { Whole physiotherapy } \\
\text { process }\end{array}$ & $\begin{array}{l}\text { Organisations, multi- } \\
\text { professional } \\
\text { rehabilitation }\end{array}$ \\
\hline Emotions & $\begin{array}{l}\text { Negative emotions } \\
\text { dominate }\end{array}$ & Coping with emotions & $\begin{array}{l}\text { Dealing with emotions } \\
\text { with a professional } \\
\text { attitude }\end{array}$ & $\begin{array}{l}\text { Dealing with } \\
\text { emotions } \\
\text { professionally and } \\
\text { collaboratively }\end{array}$ \\
\hline $\begin{array}{l}\text { Cultural } \\
\text { awareness }\end{array}$ & $\begin{array}{l}\text { Knowing other } \\
\text { cultures }\end{array}$ & $\begin{array}{l}\text { Comparing cultural } \\
\text { differences }\end{array}$ & $\begin{array}{l}\text { Widening one's own } \\
\text { cultural concept of PT }\end{array}$ & $\begin{array}{l}\text { Ruminating over } \\
\text { different social and } \\
\text { health care } \\
\text { approaches }\end{array}$ \\
\hline $\begin{array}{l}\text { Professional } \\
\text { agency }\end{array}$ & $\begin{array}{l}\text { Focusing on ones' own } \\
\text { skill development and } \\
\text { growing as a person }\end{array}$ & $\begin{array}{l}\text { Application of } \\
\text { theoretical knowledge } \\
\text { in practice }\end{array}$ & $\begin{array}{l}\text { Evaluating and } \\
\text { developing PT } \\
\text { practices }\end{array}$ & $\begin{array}{l}\text { Evaluating different } \\
\text { social and health care } \\
\text { systems }\end{array}$ \\
\hline
\end{tabular}

